\title{
Pengaruh Akuntabilitas, Gaya Kepemimpinan, Kompetensi dan di Mediasi Motivasi Terhadap Kinerja Organisasi
}

\author{
Isma Arum Wardiana"*, Suwardi Bambang Hermanto² \\ ${ }^{12}$ Sekolah Tinggi Ilmu Ekonomi Indonesia Surabaya \\ 1ismawardiana28@gmail.com, 2sbhermanto@stiesia.ac.id \\ *)Penulis korespondensi
}

\begin{abstract}
This research aimed to find out the effect of accountability, leadership style, competency and motivation on the organization performance, especially in government organization, Sidoarjo. The data collection thecnique used simple random sampling. Furthermore, there were 111 respondents as sample in 34 village area, Sidoarjo. Moreover, the data analysis thecnique used PLS (Partial Least Square. The research result concluded the transformasional leadership style had positive effect on the performance and motivation of managerial porformance. Furthermore, the managerial ownership had positive effect on the motivation managerial work. Furthermore, this research had correlated with the government support to create a good governance.
\end{abstract}

Keywords: accountability, leadership style, competency, motivation, performance

\begin{abstract}
Abstrak
Penelitian ini bertujuan untuk mengetahui pengaruh akuntabilitas, gaya kepemimpinan, kompetensi dan motivasi terhadap kinerja organisasi, khususnya pada organisasi pemerintahan desa di Kabupaten Sidoarjo. Sampel pada penelitian ini diambil dengan menggunakan metode pengumpulan data dengan simple random sampling. Jumlah sampel yang digunakan yaitu sebanyak 111 responden yang berada di 34 wilayah desa di Kabupaten Sidoarjo. Data yang diperoleh dianalisis menggunakan teknik analisis PLS (Partial Least Square). Hasil penelitian menunjukkan bahwa gaya kepemimpinan transformasional berpengaruh positif terhadap kinerja dan motivasi kerja manajerial. Selanjutnya kompetensi manajerial berpengaruh positif terhadap motivasi kerja manajerial. Penelitian ini memiliki keterkaitan dengan praktik dalam mendukung pemerintahan desa dalam menciptakan tata kelola yang baik.
\end{abstract}

Kata Kunci: akuntabilitas, gaya kepemimpinan, kompetensi, motivasi, kinerja 


\section{PENDAHULUAN}

Pengelolaan organisasi publik bersumber pada tata kelola yang baik, dikarenakan dengan adanya pedoman yang jelas dalam pengelolaan, diharapkan akan membawa dampak yang baik bagi kemajuan organisasi. Didalam sebuah organisasi terdapat sumber daya manusia yang berperan sebagai unsur pelaksanaan dari sebuah organisasi. Sumber daya manusia juga bisa menjadi suatu kendala yang dihadapi oleh organisasi, dikarenakan tidak semua sumber daya manusia mampu melaksanakan tugasnya dengan baik. Hal ini akan berdampak kepada kinerja organisasi untuk capaian tujuan dengan hasil yang baik. Agar kinerja organisasi terwujud dengan baik maka harus menjalankan beberapa indikator kinerja organisasi itu sendiri.

Kinerja organisasi publik di Indonesia dalam memberikan pelayanan publik sekarang ini dirasakan masih kurang hampir setiap saat beberapa media melaporkan ketidakpuasan masyarakat terhadap kinerja pemerintah daerah, baik kabupaten maupun Kota. Ketidakpuasan tersebut terlihat dalam beberapa unjuk rasa. Sementara itu menurut hasil laporan Badan Pengawasan Keuangan dan Pembangunan atau biasa disingkat BPKP, perasaan kecewa yang dirasakan publik atas penyelenggaraan kepemerintahan didasarkan pada ketidakpuasan masyarakat terhadap pertanggungjawaban yang diberi kepada pengelola negara atas kepercayaan yang diberikan kepada mereka.

Tuntutan tata kelola yang baik juga berlaku bagi organisasi desa. Undang-undang Republik Indonesia No. 6 Tahun 2014 pasal 4 menjelaskan bahwa salah satu tujuan pengaturan desa, yaitu membentuk pemerintahan desa yang profesional, efisien dan efektif, terbuka serta bertanggung jawab. Pemerintah desa akan bekerja untuk menyelenggarakan urusan pemerintah dalam usaha mengatur dan mengurus keperluan masyarakat setempat berdasarkan pada sejarah dan adat istiadat. Dalam lingkup pemerintah desa, kepala desa dan perangkat desa sebagai pelaksana tugas di desa diharapkan mampu melakanakaan tugas pemerintah desa dengan baik agar tercipta pembangunan dan kesejahteraan masyarakat di desa.

Saat ini, pelayanan publik desa sudah banyak mendapatkan sorotan dari masyarakat. Karena dengan adanya kebebasan berpendapat banyak di temukan kritikan-kritikan kepada kinerja aparat pemerintah desa. Dalam beragam situasi, organisasi/perangkat desa mengalami beberapa masalah seperti perangkat desa masih belum mampu dalam hal mendengarkan keluhan yang disampaikan oleh masyarakatnya. Rendahnya produktifitas dalam bekerja dan kurangnya disiplin dari aparat desa dan sarana kerja yang kurang memadai, serta rendahnya perangkat desa dalam melihat situasi yang berkembang di masyarakat.

Akuntabilitas merupakan kemampuan dari suatu organisasi sektor publik untuk memberikan arahan atas perilaku yang dilakukan terutama pihak didalam sistem politik yang telah diberi wewenang untuk menjalankan penliaian serta evaluasi terhadap publik. Akuntabilitas diharapkan dapat memperbaiki kualitas beserta kinerja dari organisasi agar dapat berorientasi pada kepentingan publik. Konsep dari akuntabilitas didasarkan pada individu atau kelompok jabatan dalam setiap klasifikasi jabatan bertanggung jawab pada kegiatan yang dilakukannya. Penelitian (Hwang, 2013) menyampaikan hasil yang positif bahwa ketika keharusan akuntabilitas dikelola dengan baik, maka akuntabilitas secara langsung maupun 
tidak dapat meningkatkan kinerja organisasi dan pelayanan publik dikarenakan manajemen memandang akuntabilitas sebagai prosedur dalam pencapaian pelayanan publik yang baik.

Gaya kepemimpinan transformasional, kompetensi manajerial serta motivasi kerja manajerial yaitu merupakan faktor organisasi. Agar tercipta kinerja oragnisasi yang baik maka gaya kepemimpinan yang ada di desa memiliki keterkaitan yang erat dengan kinerja organisasi, dimana pimpinan merupakan sebuah indikator yang penting untuk pembangunan dalam sebuah organisasi. Hubungan antara kepala desa dengan perangkat desa akan lebih memiliki hubungan yang serius dimana diharapkan terciptanya kondisi yang mempermudah terjadinya suatu musyawarah sehingga memiliki kontrol sosial serta persetujuan ataupun penolakan yang disertai dengan alasan yang logis. Gaya kepemimpinan yang baik akan meningkatkan semangat perangkat desa dalam bekerja agar dapat meningkatkan kinerjanya.

Kepala desa serta perangkat desa dalam melakukan pekerjaannya akan memerlukan kompetensi kerja untuk mendukung kinerjanya. Kompetensi merupakan keahlian, pengetahuan serta tingkahlaku yang wajib dimiliki serta dikuasai oleh setiap perangkat desa dalam meaksanakan tugas keprofesiannya. Dengan berjalannya waktu peran serta tanggungjawab dari perangkat desa di masa yang akan datang akan semakin canggih, sehingga menuntut perangkat desa agar lebih senantiasa melakukan segala peningkatan penguasaan kompetensi. Masalah kompetensi itu menjadi sangat penting dikarenakan kompetensi merekomendasikan suatu kerangka kerja organisasi yang efisien dan efektif dalam penggunaan sumber daya yang terbatas.

Perangkat desa memerlukan suatu dorongan serta motivasi untuk meningkatkan pekerjaannya. Motivasi sebagai suatu proses yang memiliki sifat internal dan/atau eksternal bagi setiap individu yang menimbulkan sikap persistensi dan antusiasme dalam melaksanakan kegiatan-kegiatan tertentu. Motivasi itu sendiri sangat bernilai dikarenakan motivasi merupakan hal yang menyebabkan dan juga mendukung tingkah laku dari manusia agar mampu bekerja dengan giat untuk mencapai hasil yang optimal. Motivasi kerja itu sendiri merupakan sebuah faktor pendorong untuk melakukan setiap pekerjaan. Bagi perangkat desa motivasi kerja dapat memacu untuk bekerja lebih keras dan giat lagi sehingga bisa meningkatkan kreativitas pekerjaan dari perangkat desa srta akan mempegaruhi sebuah pencapaian pada tujuan pemerintahan desa. Peranan motivasi perangkat desa dalam bekerja sangatlah penting dikarenakan motivasi itu sendiri sangat berhubungan dengan kinerja, jika motivasi tersebut tinggi maka kinerja dari perangkat desa itu juga akan tinggi, begitu juga sebaliknya.

Kabupaten Sidoarjo yang menjadi salah satu dari penyangga Ibu Kota Provinsi Jawa Timur adalah daerah yang mengalami pengembangan pesat. Kabupaten Sidoarjo itu sendiri termasuk dalam golongan kawasan GerbangKertosusila. Berbagai keberhasilan yang telah dicapai karena beberapa potensi yang ada di wilayah Kabupaten Sidoarjo dapat dikemas dengan baik dan terarah. Unit pemerintahan yang dikoordinir secara langsung oleh kabupaten Sidoarjo adalah kecamatan, dalam masing-masing kecamatan terdiri dari beberapa desa atau kelurahan. Kabupaten Sidoarjo terdiri atas 18 kecamatan yang terbagi atas 322 wilayah desa dengan total penduduk per 30 April 2018 mencapai total 2.216.799 jiwa. Pengelolaan administrasi pemerintahan di Kabupeten Sidoarjo telah didukung dengan sumber daya manusia yang cukup memadai. 
Berdasarkan latar belakang masalah diatas maka peneliti merumuskan rumusan masalah sebagai berikut: (1) Apakah akuntabilitas berpengaruh terhadap kinerja organisasi? (2) Apakah gaya kepemimpinan transformasional berpengaruh terhadap kinerja organisasi? (3) Apakah kompetensi manajerial berpengaruh terhadap kinerja organisasi? (4) Apakah gaya kepemimpinan transforrmasional berpengaruh terhadap motivasi kerja manajerial? (5) Apakah kompetensi manajerial berpengaruh terhadap motivasi kerja manajerial? (6) Apakah motivasi kerja manajerial berpengaruh terhadap kinerja organisasi?

Tujuan penelitian menyampaikan keinginan dari peneliti agar memperoleh jawaban dari permasalahan penelitian yang telah diajukan. Oleh karena itu, tujuan dari penelitian yang akan dilakukan dan dicapai oleh peneliti adalah untuk menguji pengaruh dari akuntabilitas, gaya kepemimpinan transformasional, kompetensi manajerial, dan motivasi kerja manajerial terhadap kineja organisasi, khususnya organisasi desa di Kabupaten Sidoarjo.

Akuntabilitas menjadi suatu prinsip diciptanya tata kelola menjadi penting dikarenakan menyediakan legistimasi untuk otoritas publik dan organisasi publik. Otoritas publik bukan jaminan untuk kepercayaan kepada publik sehingga akuntabilitas digunakan sebagai jaminan kepercayaan publik kepada pemerintah dengan mengisi waktu luang pemahaman antara masyarakat serta antara pemberi kuasa dan pemerintahan (Aucoin dan Heintzman 2000). Dalam berbagai situasi proses perkembangan suatu organisasi, dijelaskan ketika akuntabilitas suatu organisasi itu baik, makam akan berpengaruh pada transparansinya dan akan memperbaiki kinerja organisasinya (Dubnick, 2005).

Gaya kepemimpinan tidak hanya mengandalkan kekuatan ataupun kekuasaan dalam pencapaian tujuan organisasi, tetapi karakter yang berada didalam seseorang pemimpin yang transformasional bisa mampu mempengaruhi anggota dengan cara-cara yang sesuai dan tujuan organisasi dapat dengan mudah dicapai (Oshagbemi 2000). Penelitian yang dilakukan oleh (Legino, 2006) membuktikan bahwa gaya kepemimpinan berpengaruh positif terhadap perkembangan organisasi. Hal ini dikarenakan pimpinan dengan gaya transformasional bisa beradaptasi dengan situasi kondisi yang penuh dengan tekanan. Kepemimpinan transformasional menjadi pengaruh pemimpin antara pimpinan dan bawahannya. Para bawahan atau karyawan merasakan ada kepercayaan, loyalitas, kebanggaan dan rasa hormat kepada atasan, dan mereka akan termotivasi melakukan lebih dari apa yang telah diharapkan dan harus dapat menafsirkan dengan jelas visi organisasi, sehingga para anggota bisa menerima kredibilitas dari atasan atau pimpinan tersebut (Avolio dan Bass, 1994).

Bhardwaj (2013) melakukan analisis penelitian hubungan antara kompetensi manajerial dengan kinerja yang memiliki hasil bahwa kemampuan dalam berkomunikasi, manajemen diri, orientasi hasil, kerja tim, pengambilan keputusan dan resiko serta kreativitas adalah beberapa faktor yang dimiliki oleh pimpinan yang dengan sukses memajukan organisasi serta hasil kinerja yang efektif dan efisien. Kompetensi digunakan dalam suatu organisasi dalam mendefinisikan syarat dari suatu pekerjaan dan meningkatkan program pengembangan profesional serta digunakan untuk individu dalam panduan meningkatkan kemampuan diri (Klein dan Richey, 2005).

Kepemimpinan dari seseorang dalam organisasi secara tidak langsung yaitu faktor 
manusiawi yang memberikan motivasi menuju tujuan yang akan dicapai. Tanpa adanya kepemimpinan, sebuah organisasi hanya akan menjadi sekelompok individu yang tanpa arah serta tujuan. Menurut penelitian dari (Tucuan et al., 2014) menyatakan jika terdapat pengaruh positif antara gaya kepemimpinan dan motivasi artinya, semakin kuat pelaksanaan dan pemahaman dari kepemimpinan transformasional maka semakin baik pua motivasi kerjanya.

Kompetensi yaitu sebuah karakteristik yang mendasari individu yang berkaitan dengan evektifitas sebuah kinerja seseorang dalam bekerja. Karakteristik dasar kompetensi merupakan sepenggal dari kepribadian yang melekat pada setiap individu serta memiliki tingkah laku yang bisa di prediksi sebagai tugas dari pekerjaan. Ada dua penggunaan istilah kompetensi menurut (Prihadi, 2004) yaitu untuk menunjuk pada dunia pekerjaan yang dapat dilakukan oleh seseorang dengan kompeten. Hal ini bertumpu pada pemahaman yang umum dan berkaitan dengan jabatan, dan juga untuk melihat pada dimensi perilaku yang terdapat dibalik kinerja yang kompeten. Kompetensi mengacu pada seperanggu dari kemampuan serta perilaku yang telah dimiliki oleh setiap individu dalam menyelesaikan pekerjaan serta mencapai apa yang menjadi tujuannya. Tujuan dari organisasi akan tercapai jika ada individu atau kelompok individu yang mau bergerak dan berusaha untuk mencapainya. (Sari, 2016) berpendapat bahwa kompetensi manajerial berpengaruh positif dan signifikan terhadap motivasi kerja manajerial.

Menurut (Ranupandojo dan Husnan, 2000) motivasi menjadikan keadaan dalam diri pribadi seseorang untuk mendorong keinginan individu melakukan kegiatan tertentu untuk mencapai suatu tujuan. Menurut (Danim, 2004) ada 2 faktor yang mempengaruhi seseorang dalam bekerja yaitu faktor intrinsik dan ekstrinsik. Yang termasuk dalam Faktor intrinsik adalah prestasi yang dicapai, dunia kerja, pengakuan, tanggung jawab, dan kemajuan. Sedangkan yang termasuk dalam faktor ekstrinsik yaitu hubungan interpersonal antara atasan dengan bawahan, kebijakan administratif, kondisi kerja dan kehidupan pribadi. Memotivasi ialah sebuah cara yang biasa digunakan seseorang untuk mengenali dan mengelola diri sendiri dan orang lain. Motivasi dalam penelitian ini tidak terlepas dari konteks manusia organisasionalnya, yakni motivasi yang memengaruhi manusia organisasional dalam melakukan suatu pekerjaan. Dalam suatu pekerjaan motivasi sangatlah penting dikarenakan motivasi itu sendiri merupakan hal yang mendorong seseorang untuk berperilaku agar individu tersebut mau bekerja dengan giat dan antusias dalam mencapai hasil yang optimal. Hasil penelitian (Tika, 2006) yang menyatakan bahwa faktor yang bisa mempengaruhi kinerja yaitu motivasi.

\section{METODE}

Penelitian ini termasuk dalam jenis penelitian kuantitatif dengan menggunakan hipotesis yang bertujuan untuk menganalisis faktor-faktor yang mempengaruhi kinerja organisasi yaitu akuntabilitas, gaya kepemimpinan transformasional, kompetensi kerja manajerial, dan motivasi kerja manajerial. Populasi dalam penelitian ini adalalah Kabupaten Sidoarjo yang memiliki 18 kecamatan yang terdiri dari 322 wilayah desa dan 31 wilayah kelurahan.

Teknik pengambilan sampel yang digunakan di penelitian ini adalah probability sampling atau biasa disebut dengan pengambilan sampel secara acak dengan teknik yang digunakan adalah simple random sampling (teknik acak secara sederhana). Jumlah dari anggota sampel 
total ditentukan melalui rumus Slovin. Populasi penelitian ini terdapat 322 wilayah desa. Pada setiap desa di penelitian ini, peneliti akan memberikan 5 kuisioner. Sehingga populasi yang digunaka sebesar 1.610. berikut ini adalah rumus beserta perhitungan dari rumus slovin.

$\mathrm{n}=\frac{\mathrm{N}}{\mathrm{N} \cdot \mathrm{d}^{2}+1}$

Dimana:

$\mathrm{n}$ : jumlah anggota sampel

$\mathrm{N}$ : jumlah populasi

$\mathrm{d}^{2}$ : tingkat kepercayaan (Tingkat kepercayaan $10 \%$ atau 0,1.)

Data yang digunakan didalam penelitian ini merupakan data primer yang berasal dari jawaban responden atas kuisioner yang telah disebarkan/dibagikan. Jenis kuesioner yang digunakan didalam penelitian ini yaitu kuesioner tertutup berjenis skala yang dipakai yaitu skala likert 5 poin yang terdiri dari angka 1 jauh dibawah rata-rata, angka 2 dibawah rata-rata, angka 3 rata-rata, angka 4 diatas rata-rata, amgka 5 jauh diatas rata-rata. Skala likert 5 poin selanjutnya terdiri dari angka 1 sangat tidak setuju, angka 2 tidak setuju, angka 3 ragu-ragu, angka 4 setuju, dan angka 5 sangat setuju.

Akuntabilitas merupakan kejelasan fungsi dari tugas serta tanggungjawaban sehingga mewujudkan pengelolaan organisasi yang efektif. Diukur dengan indikator tugas dan tanggungjawab, terlibat bersama dalam evaluasi hasil, menginfokan sasaran program, menginfokan kegiatan program (Sari, 2016).

Gaya kepemimpinan transformasional merupakan pemimpin yang memiliki kedekatan untuk mempengaruhi bawahan dengan cara memberi kepercayaan, motivasi, serta dorongan dengan penerapan kepemimpinan transformasional bawahan akan merasa dipercaya serta loyal kepada pimpinannya sehingga bawahan akan termotivasi untuk melakukan lebih dari yang diharapkan. Diukur dengan memberi kepercayaan, menimbulkan rasa bangga menjadi rekan kerja, memberi motivasi untuk bekerja, menciptakan semangat kerja, memberi dorongan mencari cara baru, membuat lebih kritis atas ide, menghendaki penggunaan penalaran dan kepercayaan diri, memberikan perhtian pribadi, memberikan penghargaan (Sari, 2016). Kompetensi manajerial merupakan suatu kemampuan untuk melaksanakan suatu pekerjaan atau tugas yang dilandasi atas keterampilan dan pengetahuan serta didukung oleh sikap kerja yang dituntut oleh pekerjaan yang dikerjakan. Diukur dengan indikator memiliki pengalaman kerja, latar belakang yang berbeda bukan hambatan, mengarahkan untuk menyelesaikan pekerjaan, mendiskusikan hal-hal penting, melakukan pekerjaan tanpa bantuan, mengikuti pelatihan (Sari, 2016).

Motivasi kerja manajerial merupakan serangkaian sikap serta nilai-nilai yang dapat mempengaruhi individu untuk mencapai hal spesifik sesuai dengan tujuan individu yang berasal dari dalam dirinya. Diukur dengan adanya iklim kerja yang baik, adanya susunan rencana kerja, pemberian bonus, pemberian pujian, melaksanakan rapat rutin, kesungguhan berkomunikasi, adanya rincian prosedur (Sari, 2016). Kinerja organisasi menggambarkan sampai seberapa jauh satu kelompok organisasi berhasil melaksanakan semua kegiatan pokok sehingga mencapai visi 
dan misi. Diukur dengan jumlah kerja yang dihasilkan, keakuratan kerj, inovasi dan perbaikan proses, reputasi, tingkat tujuan, efisiensi operasi, moral personil (Sari, 2016).

Pada penelitian ini menggunakan analisis data dengan pendekatan Partial Least Square atau biasa disebut dengan PLS. PLS merupakan persamaan dari Structural Equation Modeling (SEM) yang berdasarkan komponen atau varian. (Ghozali, 2006) menjelaskan bahwa PLS yaitu pendekatan pilihan yang beranjak dari pendekatan SEM berbasis kovarian menjadi berbasis varian.

\section{HASIL DAN PEMBAHASAN}

Didalam penelitian ini, peneliti akan mengambil wilayah desa secara acak sebanyak 34 desa dari 11 kecamatan di wilayah utara, timur dan selatan dari Kabupaten Sidoarjo Karena peneliti telah mempertimbangkan banyak faktor, yaitu: (1) wilayah-wilayah tersebut dapat dijangkau oleh peneliti; (2) keterbatasan waktu penelitian yang singkat; (3) wilayah tersebut memiliki sumber daya manusia yang produktif dan kondisi sosial politik serta keamanan yang relatif stabil.

Jumlah total kuesioner yang telah dibagi dan disebarkan yaitu sebanyak 170 kuesioner (100\%). Ada 111 kuesioner (65\%) yang diisi lengkap dan dikembalikan. Jumlah kuesioner yang kembali tetapi tidak diisi secara lengkap yaitu 9 kuesioner (5\%). Sedangkan kuesioner yang tidak kembali yaitu sebanyak 50 kuesioner (30\%). peneliti telah memenuhi jumlah sampel yang telah ditentukan di bab3 yaitu sebesar 65\% dari 55\% kuesioner yang dibagikan.

Jumlah responden wanita responden wanita lebih sedikit dibanding dengan responden pria. Jumlah responden wanita sebanyak 30 orang (27\%) dan pria sebanyak 81 orang (73\%). Responden yang meiliki jabatan sebagai Sekretaris desa sebanyak 25 orang responden (23\%). 24 responden (21\%) menjabat sebagai Kaur Keuangan. Kaur Perencanaan sebanyak 21 responden (19\%). Kaur Tu dan Umum 19 orang responden (17\%). Sedangkan Kasi Pemerintahan hanya 22 orang (20\%).

Sebagian besar responden yang diteliti memiliki umur 31-40 tahun sebanyak 39 orang (35\%), yang berumur kurang dari 30 tahun sebanyak 25 orang (23\%), 31 orang memiliki umur 41-50 tahun (28\%), sedangkan yang lebih dari 50 tahun sebanyak 16 orang (14\%). Responden berpendidikan SMA 60 (54\%) responden, 50 responden berpendidikan S1 (45\%) dan hanya 1 orang (9\%) yang berpendidikan S2. Statistik deskriptif digunakan untuk menganalisis data berdasarkan pada hasil yang sudah diperoleh dari jawaban responden disetiap indikator pengukuran variabel.

Berdasarkan tabel 1, Variabel kinerja memiliki bobot range teoritis sebesar 7 sampai 35 dengan nilai rata-rata sebesar 26,57 dan standar deviasinya sebesar 2,148. Nilai ratarata 26,57 yang lebih rendah dari niliai median (27) maka diindikasikan bahwa menurut responden kinerja di pemerintahan desa mereka dirasakan masih kurang. Variabel akuntabilitas memiliki kisaran teoritis sebesar 4 sampai 20 dengan rata-rata nilai sebesar 17,69 dan juga standar deviasi sebesar 1,610. Dengan nilai rata-rata sebesar 17,69 yang dikatakan lebih rendah dari nilai median (18), dapat dikatakan bahwa akuntabilitas dari pemerintahan desa secara umum memiliki akuntabilitas yang cukup rendah. 
Tabel 1. Analisis Deskriptif

\begin{tabular}{lccccccc}
\hline & N & $\begin{array}{c}\text { Range } \\
\text { Teoritis }\end{array}$ & $\begin{array}{c}\text { Range } \\
\text { Aktual }\end{array}$ & Min & Max & Mean & $\begin{array}{c}\text { Std. } \\
\text { Deviasi }\end{array}$ \\
\hline Kinerja Organisasi & 111 & $7-35$ & $23-35$ & 23 & 35 & 26,57 & 2,148 \\
$\begin{array}{l}\text { Akuntabilitas } \\
\text { Gaya Kepemimpinan }\end{array}$ & 111 & $4-20$ & $15-20$ & 15 & 20 & 17,69 & 1,610 \\
$\begin{array}{l}\text { Transformasional } \\
\text { Kompetensi manajerial }\end{array}$ & 111 & $9-45$ & $33-45$ & 33 & 45 & 38,36 & 3,500 \\
Motivasi Kerja Manajerial & 111 & $6-30$ & $23-30$ & 23 & 30 & 25,35 & 1,631 \\
\hline
\end{tabular}

Sumber: Pengolahan data dengan PLS, 2019

Variabel gaya kepemimpinan transfomasional memiliki kisaran teoritis sebesar 9 sampai 45 dengan nilai rata-rata sebesar 38,36 dan standar deviasi 3,500. Nilai yang rata-rata yang sebesar 38,36 lebih besar dari median 37 maka dapat dikatakan responden menilai bahwa gaya kepemimpinan transformasional yang dimiliki oleh kepala desa pada pemerintahan desa sudah berjalan dengan baik.

Variabel kompetensi manajerial memiliki kisaran antara 6 sampai dengan 30 dan nilai rata-rata yang sebesar 25,35 dan nilai standar deviasainya sebesar 1,631. Nilai ratarata yang sebesar 25,35 yang lebih besar dari nilai median (25) membuktikan bahwa kompetensi yang dimiliki oleh perangkat desa secara umum memiliki kompetensi yang tinggi terhadap organisasinya.

Variabel Motivasi kerja manajerial memiliki kisaran teoritis antara 7 sampai dengan 35 dengan nilai rata-rata 29,35 dan standar deviasinya 2,142. Nilai rata-rata 29,35 lebih besar dari nilai median (29) yang berarti bahwa motivasi pada pemeerintahan desa sudah dimiliki oleh perangkat desa dengan baik.

Dalam menilai outer model terdapat tiga kriteria dalam menggunakan teknik analisa data dengan SmartPLS yaitu Validitas Konvergen (Convergent Validity), Discriminant Validity, dan Composite Reliability.

Gambar 1. Tampilan Hasil PLS Algorithm

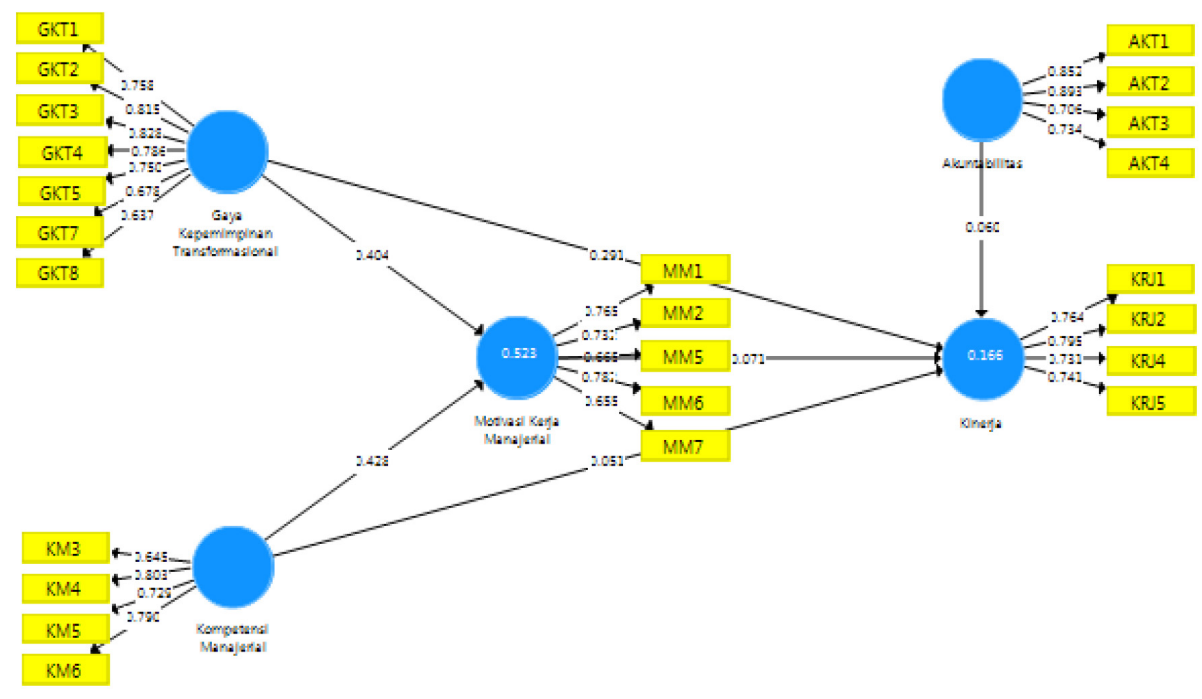


Convergent Validity Ukuran dari reflektif individual akan dikatakan tinggi jika korelasinya lebih dari 0,70 dengan konstruk yang telah diukur, akan tetapi menurut Ghazali (2006) untuk penilaian tahap awal dari pengembangan skala pengukuran nilai loading 0,5 sampai dengan 0,6 dianggap sudah cukup memadai dan didalam penelitian ini batas loading factor yang digunakan sebesar 0,60 .

Tabel 2. Outer loading

\begin{tabular}{lcc}
\hline Variabel & Indikator & Outer Loading \\
\hline Akuntabilitas & AKT1 & 0,852 \\
Gaya Kepemimpinan Transformasional & AKT2 & 0,893 \\
& AKT3 & 0,706 \\
AKT4 & GKT1 & 0,734 \\
Kompetensi Manajerial & GKT2 & 0,758 \\
& GKT3 & 0,815 \\
Kinerja & GKT4 & 0,828 \\
& GKT5 & 0,786 \\
GKT7 & 0,750 \\
Motivasi Kerja Manajerial & GKT8 & 0,678 \\
& KM3 & 0,637 \\
& KM4 & 0,645 \\
& KM5 & 0,803 \\
& KM6 & 0,729 \\
& MM1 & 0,790 \\
& MM2 & 0,765 \\
& MM5 & 0,732 \\
& MM6 & 0,665 \\
MM7 & 0,782 \\
KRJ1 & 0,655 \\
KRJ2 & 0,764 \\
& KRJ4 & 0,795 \\
& & 0,731 \\
& & 0,741 \\
\hline
\end{tabular}

Sumber: Pengolahan data dengan PLS, 2019

Berdasarkan tabel 3, variabel akuntabilitas, gaya kepemimpinan transformasional, kompetensi kerja manajerial, motivasi manajerial dan kinerja memiliki nilai AVE diatas 0,5 maka dinyatakan bahwa masing-masing variabel memiliki discriminant variabel yang baik.

Tabel 3. AVE (Average Variant Extracted)

\begin{tabular}{lc}
\hline \multicolumn{1}{c}{ Variabel } & AVE \\
\hline Akuntabilitas & 0,640 \\
Gaya Kepemimpinan Transformasional & 0,567 \\
Kompetensi Kerja Manajerial & 0,554 \\
Motivasi Manajerial & 0,521 \\
Kinerja & 0,575 \\
\hline
\end{tabular}

Sumber: Pengolahan data dengan PLS, 2019 
Uji dari discriminant validity menggunakan nilai dari cross loading. sebuah indikator akan dinyatakan memenuhi discriminant validity bila nilai dari cross loading indikator tersebut variabelnya adalah yang paling besar daripada variabel lainnya. Didalam penelitian ini setiap indikator pada variabel penelitian mempunyai nilai cross loading paling besar dibandingkan dengan nilai cross loading yang lain. Dari hasil yang sudah diperoleh, peneliti akan menyimpulkan jika dari setiap masing-masing indikator yang digunakan didalam penelitian ini memiliki discriminant validity yang cukup baik, pada Tabel 4 .

Selain itu, discriminant validity juga dapat dilihat melalui metode lain yaitu dengan melihat AVE (average variant extracted) syaratnya yaitu nilainya harus diatas 0,5 untuk model yang baikdikatakan baik, seperti Tabel 3 .

Tabel 4. Cross Loading

\begin{tabular}{lccccc}
\hline \multirow{2}{*}{ Indikator } & \multicolumn{5}{c}{ Variabel } \\
\cline { 2 - 6 } & AKT & GKT & KM & MM & KRJ \\
\hline AKT1 & $\mathbf{0 , 8 5 2}$ & 0,353 & 0,305 & 0,473 & 0,231 \\
AKT2 & $\mathbf{0 , 8 9 3}$ & 0,526 & 0,397 & 0,578 & 0,287 \\
AKT3 & $\mathbf{0 , 7 0 6}$ & 0,371 & 0,372 & 0,319 & 0,117 \\
AKT4 & $\mathbf{0 , 7 3 4}$ & 0,337 & 0,305 & 0,338 & 0,159 \\
GKT1 & 0,491 & $\mathbf{0 , 7 5 6}$ & 0,515 & 0,453 & 0,268 \\
GKT2 & 0,449 & $\mathbf{0 , 8 1 5}$ & 0,464 & 0,542 & 0,394 \\
GKT3 & 0,401 & $\mathbf{0 , 8 2 8}$ & 0,384 & 0,512 & 0,367 \\
GKT4 & 0,387 & $\mathbf{0 , 7 8 6}$ & 0,246 & 0,463 & 0,271 \\
GKT5 & 0,467 & $\mathbf{0 , 7 5 0}$ & 0,426 & 0,549 & 0,248 \\
GKT7 & 0,214 & $\mathbf{0 , 6 7 8}$ & 0,469 & 0,370 & 0,207 \\
GKT8 & 0,172 & $\mathbf{0 , 6 3 7}$ & 0,177 & 0,343 & 0,268 \\
KM3 & 0,178 & 0,248 & $\mathbf{0 , 6 4 5}$ & 0,317 & 0,187 \\
KM4 & 0,398 & 0,409 & $\mathbf{0 , 8 0 3}$ & 0,598 & 0,120 \\
KM5 & 0,276 & 0,430 & $\mathbf{0 , 7 2 9}$ & 0,408 & 0,292 \\
KM6 & 0,364 & 0,413 & $\mathbf{0 , 7 9 0}$ & 0,514 & 0,225 \\
MM1 & 0,506 & 0,444 & 0,497 & $\mathbf{0 , 7 6 5}$ & 0,202 \\
MM2 & 0,413 & 0,479 & 0,436 & $\mathbf{0 , 7 3 2}$ & 0,365 \\
MM5 & 0,361 & 0,430 & 0,447 & $\mathbf{0 , 6 6 5}$ & 0,127 \\
MM6 & 0,450 & 0,466 & 0,466 & $\mathbf{0 , 7 8 2}$ & 0,202 \\
MM7 & 0,285 & 0,424 & 0,446 & $\mathbf{0 , 6 5 5}$ & 0,227 \\
KRJ1 & 0,146 & 0,240 & 0,184 & 0,222 & $\mathbf{0 , 7 6 4}$ \\
KRJ2 & 0,180 & 0,332 & 0,230 & 0,294 & $\mathbf{0 , 7 9 5}$ \\
KRJ4 & 0,331 & 0,254 & 0,238 & 0,235 & $\mathbf{0 , 7 3 1}$ \\
KRJ5 & 0,153 & 0,343 & 0,163 & 0,206 & $\mathbf{0 , 7 4 1}$ \\
\hline
\end{tabular}

Sumber: Pengolahan data dengan PLS, 2019

Composite reliability adalah menguji nilai reliabilitas dari indikator pada suatu variabel. Composite reliability dinyatakan baik atau memenuhi jika $>0,6$ dan Jika nilai cornbatch 
alpha lebih dari 0,7 akan dinyatakan variabel tersebut memenuhi atau reliabel. Berdasarkan pada Tabel 5 menunjukan bahwa nilai Composite reliability pada semua variabel penelitian $>0,6$ dan nilai cornbatch alpha lebih dari 0,7. Dengan kata lain keseluruhan dari variabel diatas memiliki tingkat reliabilitas yang tinggi.

Tabel 5. Composite Reliability

\begin{tabular}{lcc}
\hline \multicolumn{1}{c}{ Variabel } & Composite Reliability & Cornbatch Alpha \\
\hline Akuntabilitas & 0,876 & 0,823 \\
Gaya Kepemimpinan Transformasional & 0,901 & 0,872 \\
Kompetensi Kerja Manajerial & 0,844 & 0,754 \\
Motivasi Manajerial & 0,832 & 0,733 \\
Kinerja & 0,844 & 0,768 \\
\hline
\end{tabular}

Sumber: Pengolahan data dengan PLS, 2019

Langkah pertama untuk menilai innermodel dengan Partial Least Square dilihat dengan $R$-square untuk masing-masing variabel laten dependen. Penelitian ini menggunakan 2 variabel yang dipengaruhi oleh variabel lain antaralain yaitu Kinerja (KRJ) dan Motivasi Kerja Manajerial (MM). Tabel dibawah ini adalah hasil dari estimasi $R$-square dengan menggunakan Smart Partial Least Square.

Tabel 6. Nilai R-Square

\begin{tabular}{lc}
\hline \multicolumn{1}{c}{ Variabel } & Nilai $\boldsymbol{R}$-square \\
\hline Kinerja & 0,166 \\
Motivasi Kerja Manajerial & 0,523 \\
\hline
\end{tabular}

Sumber: Pengolahan data dengan PLS, 2019

Tabel 6 menunjukkan bahwa nilai $R$-square untuk variabel kinerja diperoleh sebesar 0,166 dan variabel motivasi kerja manajerial sebesar 0,523 . Didalam penelitian ini, pengujian hipotesis akan dilakukan denga melihat T-Statistics serta nilai $P$-Values $<0,05$. Dibawah ini merupakan hasil dari uji hipotesis yang didapatkan melalui inner model.

Tabel 7. Path Coefficient (Mean, STDEV, T-Value, P-Value)

\begin{tabular}{lccccc}
\hline & $\begin{array}{c}\text { Original } \\
\text { Sample (0) }\end{array}$ & $\begin{array}{c}\text { Sample } \\
\text { Mean (M) }\end{array}$ & $\begin{array}{c}\text { Standard } \\
\text { Deviation } \\
\text { (STDEV) }\end{array}$ & $\begin{array}{c}\text { T-Statistics } \\
(\mid \mathbf{O} / \text { STDEV|) }\end{array}$ & P-Values \\
\hline AKT -> KRJ & 0,060 & 0,092 & 0,137 & 0,434 & 0,665 \\
GKT -> KRJ & 0,291 & 0,286 & 0,134 & 2,162 & $\mathbf{0 , 0 3 1}$ \\
KM -> KRJ & 0,051 & 0,046 & 0,124 & 0,411 & 0,681 \\
GKT -> MM & 0,404 & 0,409 & 0,092 & 4,408 & $\mathbf{0 , 0 0 0}$ \\
KM -> MM & 0,428 & 0,433 & 0,094 & 4,525 & $\mathbf{0 , 0 0 0}$ \\
MM -> KRJ & 0,071 & 0,065 & 0,156 & 0,454 & 0,650 \\
\hline
\end{tabular}

Sumber: Pengolahan data dengan PLS, 2019 
Hasil dari pengujian hipotesis yang pertama menujukkan bahwa hubungan antara variabel akuntabilitas (AKT) dengan kinerja (KRJ) membuktikan bahwa nilai koefisien jalur sebesar 0,060 dengan nilai t sebesar 0,434 nilai tersebut lebih kecil dari t tabel $(1,981)$. Hasil ini menujukkan bahwa akuntabilitas memiliki hubungan positif tetapi tidak signifikan terhadap kinerja, hal ini berarti tidak sesuai dengan hipoteis pertama dimana akuntabilitas berpengaruh positif terhadap kinerja organisasi.

Pada pengujian hipotesis yang ke dua menerangkan hubungan variabel gaya kepemimpinan transformasional (GKT) dengan kinerja (KRJ) memperlihatkan nilai koefisien jalur sebesar 0,291 dengan nilai t sebesar 2,162. Hal ini menujukkan bahwa nilai tersebut lebih besar dari t tabel $(1,981)$. Hasil ini membuktikan jika gaya kepemimpinan transformasional memiliki hubungan secara positif serta signifikan terhadap kinerja hal ini berarti sesuai dengan hipotesis kedua dimana gaya kepemimpinan transformasional berpengaruh positif terhadap kinerja organisasi.

Hasil dari uji hipotesis yang ketiga membuktikan bahwa hubungan dari variabel kompetensi manajerial (KM) dengan kinerja (KRJ) membuktikan nilai dari koefisien jalur sebesar 0,051 dengan nilai $\mathrm{t}$ sebesar 0,411. Nilai tersebut lebih kecil dari t tabel $(1,981)$. Hal ini menujukan bahwa kompetensi manajerial memiliki hubungan positif, tetapi tidak signifikan dengan kinerja. Hal ini berarti tidak sesuai dengan hipotesis ketiga dimana kompetensi manajerial berpengaruh positif terhadap kinerja.

Pengujian keempat dilakukan untuk melihat apakah pengaruh gaya kepemimpinan transformasional (GKT) berpengaruh positif terhadap motivasi kerja manajerial (MM). Hasil pengujian membuktikan nilai dari koefisien jalur sebesar 0,404 dengan nilai t sebesar 4,408 $>1,981$ ( $\mathrm{t}$-tabel) berarti variabel gaya kepemimpinan transformasional berpengaruh positif dan signifikan terhadap motivasi manajerial hal ini sesuai dengan hipotesis yang keempat dimana gaya kepemimpinan transformasional berpengaruh positif terhadap motivasi manajerial.

Pengujian hipotesis yang kelima akan memperlihatkan pengaruh kompetensi manajerial (KM) terhadap motivasi kerja manajerial (MM). Berdasarkan pada hasil pengujian memperoleh nilai koefisien jalur sebesar 0,428 dengan nilai t-statistik 4,525 dimana nilai tesebut lebih besar dari nilai t-tabel $(1,981)$. Hal ini menujukkan bahwa variabel kompetensi manajerial berpengaruh positif dan signifikan terhadap motivasi manajerial sesuai dengan hipotesis keempat dapat disimpulkan bahwa hipotesis 5 diterima.

Hasil dari pengujian hipotesis yang keenam menunjukkan bahwa hubungan motivasi kerja manajerial (MM) dengan kinerja (KRJ) menunjukkan nilai koefisien jalur sebesar 0,071 dengan nilai t-statistik sebesar 0,454 dimana nilai tersebut lebih kecil dari t-tabel $(1,981)$. Hal ini menunjukkan bahwa motivasi kerja manajerial memeiliki hubungan yang positif dengan kinerja tetapi tidak berpengaruh secara signfikan, dengan kata lain pengujian hipotesis ini tidak sesuai dengan hipotesis keenam.

Akuntabilitas tidak berpengaruh terhadap kinerja hal ini menujukkan bahwa penelitian ini sejalan dengan penelitian yang dilakukan oleh (Priyanto, 2016) dan (Jitmau, 2017) yang mengatakan bahwa akuntabilitas tidak berpengaruh terhadap kinerja. Ketidak signifikannya hipotesis ini peneliti berasumsi bahwa meskipun akuntabilitas di beberapa desa di Kabupaten 
Sidoarjo sudah baik masih belum sepenuhnya mempengaruhi kinerjanya dan dimungkinkan perangkat desa kurang memahami kuesioner yang diberikan oleh peneliti. Kinerja pemerintah desa akan dikatakan baik jika setiap yang direncanakan oleh pemerintah desa untuk mencapai hasil yang baik dan mkasimal dari perencanaan tersebut salah satunya yaitu pertanggungjawaban atas pengelolaan pemerintahan yang dilakukan secara baik dan benar.

Pengaruh gaya kepemimpinan transformasional berpengaruh terhadap kinerja. Penelitian ini sependapat dengan (Prambudi et al., 2016) yang menyatakan bahwa gaya kepemimpinan transformasional berpengaruh signifikan terhadap kinerja. Hal ini sejalan dengan penelitian yang telah dilakukan oleh (Legino, 2006) yang menunjukkan jika gaya kepemimpinan transformasional berpengaruh secara positif dengan pengembangan organisasi, dikarenakan pimpinan dengan gaya transformasional bisa menyelaraskan diri dengan keadaan yang penuh dengan tekanan. Peneliti menduga bahwa kepala desa akan memberi semangat, arahan, dorongan, serta dukungan secara penuh terhadap perangkat desa untuk meningkatkan kinerjanya. Hal ini menunjukkan bahwa perbedaan keinginan dari perangkat desa mengenai kepemimpinan kepala desa tidak menjadi hambatan untuk perangkat desa bekerja lebih giat sehingga pengaruh gaya kepemimpinan transformasional mampu mempengaruhi kinerja organisasi. Dengan menggunakan gaya kepemimpinan yang bisa membawa pemerintahan desa menuju ke arah yang lebih baik akan berdampak positif dan baik pula terhadap kinerja pemerintahan desa, seperti gaya kepemimpinan transformasional ini.

Kompetensi tidak berpengaruh terhadap kinerja. Penelitian ini sependapat dengan penelitian dari (Sari, 2016) yang menyatakan bahwa kompetensi manajerial berpengaruh tidak signifikan terhadap kinerja organisasi Peneliti menduga kompetensi bukan menjadi tolak ukuran utama dalam meningkatkan kinerja di suatu organisasi pemerintahan desa karena tidak semua perangkat desa menempuh pendidikan yang sama degan apa yang mereka kerjakan saat ini, maka tidak aneh jika kompetensi tidak berpengaruh signifikan terhadap kinerja.

Gaya kepemimpinan transformasional berpengaruh positif terhadap motivasi kerja manajerial, karena semakin baik gaya kepemimpinan transformasional yang diterapkan oleh pimpinan, maka dapat meningkatkan motivasi kerja dari pegawai tersebut. Hal ini menunjukkan bahwa gaya kepemimpinan transformasional yang telah diterapkan oleh kepala desa kepada perangkat desa diharapkan perangkat desa tersebut memiliki motivasi yang baik untuk menyelesaikan pekerjaannya sesuai yang telah diamanahkan oleh kepala desa. Semakin kuat atau baik pelaksanaan dan pemahaman dari kepemimpinan transformasional, maka semakin kuat pula motivasi kerja karyawan. Hasil penelitian ini sejalan dengan penelitian yang dilakukan oleh (Sari, 2016) yang menyatakan bahwa gaya kepemimpinan transformasional berpengaruh positif dan signifikan terhadap kinerja.

Kompetensi manajerial berpengaruh positif terhadap motivasi kerja manajerial. Hasil penelitian ini sejalan dengan penelitian (Sari, 2016) yang menyatakan bahwa kompetensi manajerial berpengaruh positif dan signifikan terhadap motivasi kerja manajerial. Terdukungnya hipotesis ini mebuktikan bahwa dengan kompetensi yang teah dimilikioleh kepala desa dan perangkat desa, maka mereka akan merasa lebih termotivasi dikarenakan dengan kompetensi yang dimiliki tersebut maka akan lebih mudah dalam melakukan pekerjaannya. Tingginya kompetensi sesorang dalam bidang pekerjaannnya maka semakin tinggi pula 
motivasi kerjanya. Hal ini menjelaskan bahwa ketika kepala desa bekerja sesuai dengan kompetensinya, maka diharapkan mampu memiliki motivasi kerja yang tinggi untuk bisa menyelesaikan pekerjaan tersebut. Jika suatu individu termotivasi untuk bekerja lebih baik, maka akan tercipta kinerja yang baik pula, begitu juga sebaliknya.

Motivasi kerja manajerial tidak berpengaruh terhadap kinerja organisasi. Penelitian ini juga sejalan dengan (Sari, 2016) yang mengatakan bahwa motivasi kerja manajerial berpengaruh tidak signifikan terhadap kinerja. Ketidak terdukungnya menunjukkan bahwa tidak semua motivasi yang diberikan kepala desa terhadap perangkat desa bisa memberikan dampak kepada kinerjanya, oleh karena itu butuh kesadaran dari diri individu untuk merubah dirinya masing-masing sehingga tercipta kinerja yang baik. Meskipun kepala desa sudah memotivasi perangkat desa dengan sangat baik untuk kemajuan organiasai tetapi perangkat desa masih belum tergugah atau belum ingin merubah sikapnya maka kinerja juga belum bisa terpengaruh.

\section{SIMPULAN}

Hipotesis yang berhasil diterima antara lain pertama, hasil dari pengujian hipotesis $\mathrm{H} 2$ menunjukkan bahwa ada hubungan yang positif dan signifikan antara gaya kepemimpinan transfromasional terhadap kinerja. Hal ini berarti kepala desa memiliki kepercayaan dan perasaan yang begitu baik terhadap perangkat desa, agar tercipta kinerja organisasi pemerintahan yang baik serta meningkatkan kinerja dari organisasinya. Kedua, hasil dari uji hipotesis H4 membuktikan bahwa gaya kepemimpinan transformasional ada hubungan yang positif dan signifikan dengan motivasi kerja manajerial, hal ini berarti perangkat desa memiliki motivasi yang baik dari kepala desa untuk menyelesaikan pekerjaan dan tugas nya dengan efektif dan efisien untuk meningkatkan kinerja organisasi pemerintahan desa tempat mereka bekerja. Ketiga, hasil dari H5 menjelaskan bahwa ada pengaruh yang positif dan signifikan antara kompetensi manajerial dengan motivasi kerja manajerial, hal ini menunjukkan bahwa perangkat desa di Kabupaten Sidoarjo telah memahami kemampuan dan motivasinya untuk menyelesaikan pekerjaannya agar tercapai target dari pemerintahan desa menjadi lebih baik dan meningkat. Hipotesis yang ditolak terdiri dari pertama, hasil dari uji hipotesis H1 menunjukkan hubungan yang tidak berpengaruh antara akuntabilitas dan kinerja. Hal ini berarti bahwa meskipun akuntabilitas dalam organisasi pemerintahan desa dan sikap akuntabilitas internal perangkat desa sudah baik tetapi masi belum bisa meningkatkan ataupun mendorong kinerja dari organisasi pemerintahan desa. Kedua, hasil uji hipotesis H3 menjelaskan bahwa tidak ada pengaruh antara kompetensi manajerial dengan kinerja organisasi. Karena, meskipun perangkat desa tidak memiliki pengalaman pekerjaan dalam bidang yang dikerjakan saat ini dan latar belakang pendidikan yang berbeda bukan menjadi hambatan untuk meningkatkan kinerja organisasi pemerintahan desa menjadi lebih baik. Ketiga, hasil dari uji hipotesis yang terakhir yaitu $\mathrm{H6}$ menunjukkan bahwa motivasi kerja manajerial tidak memiliki pengaruh dengan kinerja. Karena, meskipun perangkat desa telah termotivasi untuk bekerja lebih giat dan antusias tetapi masih belum ada kesadaran dari perangkat desa tersebut untuk bergerak maka kinerja dari pemerintah desa belum bisa mencapai hasil yang optimal.

Kontribusi bagi pemerintah Kabupaten Sidoarjo yang menjadi objek penelitian, diharapkan informasi ini dapat memberikan kontribusi pemikiran yang bermanfaat bagi 
pemerintahan desa. Diharapkan pula penelitian ini bisa digunakan sebagai input terkait dalam pengembangan desa dengan mengoptimalkan kinerja organisasi desa. Penulis berharap penelitian ini bisa menambah wawasan dan pengetahuan penulis dalam masalah kinerja organisasi desa di Kabupaten Sidoarjo, khususnya tentang profil akuntabilitas, gaya kepemimpinan, kompetensi dan motivasi pada organisasi desa.

Keterbatasan dalam penelitian ini yaitu: (1) beberapa dari butir pernyataan yang ada di dalam kuisioner penelitian ini adalah konsep yang digunakan secara umum dan tidak spesifik untuk organisasi pemerintahan desa. Maka dari itu, hal ini akan mempenngaruhi kualitas kuisioner yang digunakan menjadi media pengumpulan data; (2) sampel yang digunkan dalam penelitian ini hanya 34 desa yang ada di 11 kecamatan di wilayah timur, selatan serta utara Kabupaten Sidoarjo; (3) data dalam penelitian ini merupakan sebuah hasil presepsi dari seorang responden sehingga bisa menimbulkan masalah jika presepsi dari responden didalam mengisi kuisioner ini berbeda dengan keadaan yang sesungguhnya.

Saran dari peneliti dalam penelitian ini yaitu: (1) sampel didalam penelitian ini hanya berasal dari 11 kecamatan yang terdiri dari 34 desa yang berada di Kabupaten Sidoarjo bagian timur, selatan, dan utara sehingga harapan peneliti pada penelitian selanjutnya dapat dilakukan dengan memperbanyak sampel serta memperluas jumlah kecamatan dan kantor desa yang akan dijadikan objek penelitian; (2) peneliti berharap penelitian selanjutnya dapat melakukan pengujian dengan menggunakan model yang lebih diuraikan, hingga hasil penelitian bisa lebih memberi gambaran yang lebih baik lagi; (3) penelti berharap dipenelitian selanjutnya bisa menggunakan metode penelitian yang mendukung dengan hasil penelitian ini agar tidak terjadi kesalahpahaman.

\section{PUSTAKA ACUAN}

Aucoin, P. dan R, Heintzman. (2000). The Dialetics of Accountability for Performance in Public Management Reform. International Review if Administration Science (66). 45- 55.

Avolio, B. J. dan B. M, Bass. (1994). Improving organizational effectiveness through transformational leadership. CA: Sage Thousand Oaks.

Bhardwaj, A. (2013). Managerial Competencies and Their Influence on managerial Performance. International Journal of Advanced Research in Management and Social Sciences. 5 (2).

Danim, S. (2004). Motivasi Kepemimpinan \& Efektivitas Kelompok. PT Rineka Cipta. Jakarta

Dubnick, M. (2005). Accountability and the Promise of Performance: In Search of the Mechanisms. Performance \& Management Review (3). 76-417.

Fiedler, F. A. (2007). Atheory of Leadership Effectiveness.Mc. GrawHill Book CO. New York. Ghozali, I. (2006). Aplikasi Analisis Multivariate Dengan Program SPSS. Cetakan Keempat. Badan Penerbit Universitas Diponegoro. Semarang.

Ghozali, I. (2009). Aplikasi Analisis Multivariate Dengan Program SPSS. Edisi Keempat. Badan Penerbit Universitas Diponegoro. Semarang.

Hwang, K. (2013). The Impact of Accountability and Accountability Management on Performance at the Street Level. Disertasi, Virginia Polytechnic Institute and State University.

Jitmau, F., L. Kalangi, L. Lambey. (2017). Pengaruh Akuntabilitas Transparansi dan Fungsi 
Pemeriksaan Intern terhadap Kinerja Pemerintah Daerah (Studi Empiris di Kabupaten Sorong). Jurnal Riset Akuntansi dan Auditing "Goodwill" 8 (1).

Kooiman, J. (2003). Governing as Governance, SAGE.

Legino, S. (2006). Public Sector Leadership Perspectives on the Lateral Capability of Public Sector Organizations. Disertasi, School of Business and Technology, Webster University. Lembaga Administrasi Negara. (2003). SANKRI Buku 1 Prinsip-prinsip Penyelenggaraan Negara. LAN. Jakarta.

Mahmudi. (2010). Manajemen Kinerja Sektor Publik. UPP STIM YKPN. Yogyakarta.

Mardiasmo. (2004). Akuntansi Sektor Publik. Penerbit Andi. Yogyakarta.

Mardiasmo. (2006). Pewujudan Transparansi dan Akuntabilitas Publik Melalui Akuntansi Sektor Publik: Suatu Sarana Good Governance, Jurnal Akuntansi Pemerintah 2(1). 1-17 Muhaimin. (2004). Wacana Pengembangan Pendidikan Islam. Pustaka Pelajar. Yogyakarta.

Oshagbemi, T. (2000). How Satisfied are Academics with Their Primary Tasks of Teaching, Research and Administration and Management?. International Journal of Sustainability in Higher Education, 1(2). 124-136.

Prambudi, S. D., D. Mukzan, G. E. Nurtjahjono. (2016). Pengaruh Gaya Kepemimpinan Transformasional terhadap Kinerja karyawan melalui Kepuasan Kerja Karyawan sebagai variabel Mediasi. Jurnal Adminnistrasi Bisnis 39(1).

Prawitasari, J. E. (2012). Psikologi terapan: melintas batas disiplin ilmu. Erlangga. Jakarta.

Prihadi, S. F. (2004). Assessment Centre: Identifikasi, pengukuran dan Pengembangan Kompetensi. Gramedia Pustaka Utama. Jakarta.

Priyanto, B. W. (2016). Pengaruh Gaya Kepemimpinan Transformasional dan Kompetensi terhadap Kinerja Karyawan dengan Motivasi sebagai variabel intervening. E journal umm 7(2). 105-114.

Ranupandojo, H. dan S, Husnan. (2000). Manajemen Personalia. BPFE UGM. Yogyakarta.

Richey, R. C. dan J. D. Klein. (2005). Developmental research methods: Creating knowledge from instructional design and development practice. Journal of Computing in higher Education.16. 23-38.

Robbins, B. J. dan Judge. (2008). Perilaku Organisasi. Buku 2, Salemba Empat. Jakarta.

Sari, M. R. (2016). Pengaruh Akuntabilitas, Faktor Organisasional dan Penggunaan Sistem Pengukuran Kinerja terhadap Kinerja Organisasi. Jurnal Akuntansi dan Keuangan Indonesia 13(2). 117-141.

Tika, M. P. (2006). Budaya Organisasi dan Peningkatan Kinerja Perusahaan, Cetakan Pertama, PT. Bhumi Aksara, Jakarta.

Tucunan, R. J. A., W. G. Supartha, dan I. G. Riana. (2014). Pengaruh Kepemimpinn Transformasional teerhadap Motivasi dan Kinerja Karyawan. E-jurnal Ekonomi dan Bisnis Universitas Udayana. 3(9). 533-550.

Undang-Undang Republik Indonesia Nomor 6 Tahun 2014. 15 Januari 2014. Lembaran Negara Republik Indonesia Tahun 2014 Nomor 4301. Jakarta.

Yukl, G. (1994). Leadership in Organisations. Terjemahan Jusuf Udayana. Kepemimpinan dalam Organisasi. Edisi 3. Prenhallindo. Jakarta. 